\title{
NEW ITALIAN LANGUAGES
}

\section{CATERINA ROMEO}

\begin{abstract}
Sommario
Questo saggio analizza come, in Italia, le scrittrici migranti (e postmigranti) contemporanee stiano cambiando la lingua nazionale dallinterno. Scrivendo in italiano, queste autrici aspirano ad essere accettate come parte integrante del discorso nazionale italiano - socialmente, politicamente, culturalmente, artisticamente - ed inoltre vogliono che la cultura italiana sia pronta ad accettare e comprendere le differenze presenti allinterno di una presunta omogeneità. Al rapporto istituzionale instaurato dalla legge, che le classifica come "ospiti indesiderati", rispondono attraverso $i$ loro testi mettendo in discussione la nozione stessa di "italianità". Se la condizione di scrittore è una strategia per acquistare autorità, questi artisti stanno rivendicando - e stanno ottenendo - il diritto di diventare soggetti (legali) presenti a pieno titolo all'interno della cultura italiana.
\end{abstract}

In the prize-winning short story 'Documenti, prego', writer Ingy Mubiayi, of Egyptian and Congolese origins, refers to Dante Alighieri, the "father" of the Italian language, with apparent disrespect and subtle irony. She compares the voyage that her family has undertaken through the meanderings of bureaucracy to apply for Italian citizenship to Dante's voyage in the Underworld. In both cases the voyage is long and painful, in both cases it is cathartic and leads to salvation: for Dante, the salvation of eternal life, for them, the salvation of Italian citizenship. Unlike the "sommo poeta", however, who descends into the inferno guided by Virgil, the only guidance that Mubiayi's protagonist and her family receive is from a paper sheet with the information about the application process. This leads them 
through courts, consulates, district offices, central offices, banks, the central police station - on whose door the protagonist has inscribed the words that Dante reads on the gate of the inferno, "Lasciate ogni speranza voi ch'entrate" ("Abandon all hope, you who enter here") and finally to purification ${ }^{1}$. The short story ends with another gentle mockery of the Italian glorious past, when the main character describes her brother's stupefied expression as "indegna di un poeta, di un santo o di un navigatore" (Mubiayi 2005:107) ("not worthy of a poet, of a saint, or of a sailor") $)^{2}$. Although legally they have become Italian citizens, their difference is and will continue to be inscribed on their faces. They can become new Italians, but they will never be able to gain access to the past that makes Italy one of the pillars of Western culture and civilization.

If a share in the magnificence of Italian history is denied to the characters in her story, Ingy Mubiayi has nevertheless gained access to Dante's language, which she alters from the inside and reinvents. With the due differences, Bhabha's notion that a culture which is "the same but not quite" in relation to the mainstream (for Bhabha the culture of the colonizer) can pose a threat to the very notion of sameness and homogeneity can be applied also to the literature of

1 All translations in this article are my own unless otherwise specified. Aware of the fact that a translation is always a process of mediation and never a transparent operation, I always include the Italian original texts. In very few exceptions - when quotations are very brief or non-problematic (like, for instance, a list of objects) - I privilege the smoothness of reading and omit the original text in Italian.

2

Italians ironically define themselves as "un popolo di poeti, di santi e di navigatori" ("a people of poets, saints, and sailors). When Benito Mussolini delivered his speech to the Italian nation to announce that Italy was at war with Ethiopia on October 2, 1935, he referred to the Italian people as "questo popolo di poeti, di artisti, di eroi, di santi, di navigatori, di trasmigratori, ("this people of poets, artists, heroes, thinkers, scientists, sailors and migrants"). These words are also inscribed on all the four façades of the Palazzo della Civiltà Italiana in Rome, also known as "Palazzo della Civiltà del Lavoro" or "Colosseo Quadrato" (Square Colosseum): "UN POPOLO DI POETI DI ARTISTI DI EROI DI SANTI DI PENSATORI DI SCIENZIATI DI NAVIGATORI DI TRASMIGRATORI". For Mussolini's speech, see G. Rochat, Il colonialismo italiano, Torino, Loescher, 1974:163-64. 
migrant and post-migrant writers in Italy ${ }^{3}$. They mimic, rather than simply employing, the Italian language, by often introducing foreign words that become part of their narrative, altering Italian grammar and syntax, and representing experiences that do not generally become incorporated into mainstream Italian literature. In the "repetitious slippage" (Bhabha 1994:90) created by a sameness which is not quite the same, a threat to mainstream hegemony is posed ${ }^{4}$.

The roles of women in contemporary transnational movements and in the geopolitical re-mapping of the world are crucial in the process of reshaping both the cultures they leave behind and those they come to inhabit. The ways in which these roles are represented by migrant and post-migrant women writers often revolve around the various conflicts that arise in the process of "assimilation" and in the continuous negotiations of identity that this process implies. Not only do migrant and post-migrant women writers often encounter the resistance of mainstream Italian culture, they also question their traditional, domestic roles within the patriarchal cultures and communities that fostered them. Moreover, these women often criticize the very notion of universal "sisterhood" among women, denouncing the fact that Italian women have - at least in part - been able to abandon the domestic space only because immigrant women

3 For a lengthy discussion and problematization of the term "post-migrant," see my book in progress on migrant and post-migrant women writers in contemporary Italy.

While I employ Bhabha's notion of "mimicry" here, I am perfectly aware of the profound differences of the contexts that Bhabha and I examine. In using a notion that has been coined for the postcolonial discourse of India, I do not mean to equate the relationships colonizer/colonized and mainstream/migrant, or to disregard differences in history and geography. I am also aware of the fact that in the context I analyze, strictly speaking, there is no "imposition" of language as there was in colonial India. I choose to employ Bhabha's theory, in spite of the numerous differences, because I find his formulation interesting for my analysis of sameness and of the ways in which this is questioned and disrupted in the representations of migrant writers. Particularly relevant in Bhabha's theory is the turn "from mimicry - a difference that is almost nothing but not quite - to menace - a difference that is almost total but not quite" (1994: 91) and the potentially disruptive power existing in the gap between "same" and "not quite." In mimicking - not simply employing - the language of the country they come to inhabit, migrant and post-migrant writers also question and disrupt it. 
have come to occupy it. As Barbara Ehrenreich and Arlie Russell Hochschild highlight in their introduction to Global Woman: Nannies, Maids, and Sex Workers in the New Economy, immigrant women's contribution to Western domestic households is only part of a larger importation of different kinds of love and its surrogates - from nannies to sex workers - which seem to have become increasingly lacking in wealthy countries around the world. But this love importation is part of an economic system in which women subjugate other women, a system which maintains and perpetuates global inequality.

The intersection of gender and migration is further complicated by Sandra Ponzanesi's introduction of the postcolonial discourse in an Italian context. In her Paradoxes of Postcolonial Cultures, Ponzanesi compares literatures written by women of the Indian diaspora, who write in English, with writings by African Italian authors, who write in Italian. Assuming Deleuze and Guattari's notion of "minor literature" as a point of departure - "A minor literature doesn't come from a minor language, it is rather that which a minority constructs within a major language" (Deleuze and Guattari 1986:16) - Ponzanesi claims that African Italian literature can be defined as minor not only with respect to mainstream Italian literature, but also with respect to Anglophone postcolonial literatures, which occupy a central position in postcolonial discourse because of the centrality of the English language in a global context. African Italian literature, therefore, enacts resistance both within the dominant postcolonial and the Italian canon. However, Ponzanesi also underlines the importance of remembering that "minor" is a relative term, and that what can be considered as "minor" in a certain context, or historical period, can become "major" in another, and vice versa. In order to avoid the binary opposition major/minor, it is necessary to constantly rethink one's location and be willing to reposition oneself.

The questions that feminist and postcolonial critics have asked concerning how to inscribe difference in a language while at the same time inhabiting it are crucial in cases of transnational cultures and 
migrant literatures. Writers coming from different geopolitical locations have different approaches to and perspectives on the Italian language. For "proper" postcolonial writers in Italy, such as Shirin Ramzanali Fazel (Somalia), Ribka Sibhatu (Eritrea), Maria Abbebù Viarengo (of Ethiopian mother and Piedmontese father), and Gabriella Ghermandi (also of Ethiopian mother and Italian father), Italian constitutes the colonial language and employing it in their writings is part of their postcolonial resistance. For a second generation of postcolonial writers, which includes Igiaba Scego (of Somali origins) and Ubax Cristina Ali Farah (of Italian mother and Somali father, born in Italy, raised in Mogadishu), Italian constitutes their first language and this gives them the freedom and the confidence to experiment with it and to show irreverence toward Italian culture. For other postcolonial writers such as Nassera Chohra - born in France into an Algerian family of Saharawi origins - Italian constitutes neither her family's language of origin nor of adoption. In her Volevo diventare bianca, Chohra's choice of Italian as the language of her narrative is an eloquent sign of the distance - at least partial - that the author wants to create with her past, both with her parents' land and language of origin and with the language of the colonizers. Other authors who write in Italian come to Italy from non-Italian postcolonial contexts, such as Genevieve Makaping (Cameroon), Laila Wadia (India), and Christiana de Caldas Brito (Brazil), and others come from geographical zones with different histories, as is the case for Salwa Salem (Palestine), or from former Communist Eastern Europe, as Jarmila Očkayová (Slovakia) and Ornela Vorpsi (Albania). Finally, there are authors whose identity is formed at the intersection of so many trajectories that it would be limiting to try and label them: Ingy Mubiayi (born in Cairo from Egyptian mother and Congolese father, lives in Rome) and Gabriella Kuruvilla (who authored her first book under the pseudonym of Viola Chandra, born in Italy from Indian father and Milanese mother), only to name a few, are very lively presences in Italian literature and culture. 
For some of these writers, Italian represents their first language, and for some of them the only one. Some have chosen Italy and Italian because of its proximity to their countries or to the countries to which they had previously migrated. Some have found themselves in Italy and have approached Italian almost by chance. The paths that led them to the use of the Italian language are as different as they are relevant: what these authors have in common is their often unconventional uses of Italian, which are having a strong impact on the national culture and literature while at the same time questioning the very notion of nation. A Brazilian cleaning lady who works in an Italian household is rehearsing her speech in which she intends to disclose to her employer the news that she no longer desires to live in Italy and work for her. She cannot get accustomed to the coldness of her new life, to the grayness of the people. Saudade, a combination of longing and sadness, is so strong that it has become an illness for her, and therefore she has resolved to return to her native country. Her name is Ana de Jesus and she is the protagonist of Christiana de Caldas Brito's short story by the same name:

Signora, io non trovo bene qui.

No. Non subito così. Meglio un po' alla volta.

Permesso, signora? Desidero parlare. Io tengo piccolo problema e voglio risolvere con te.

Sì, quando lei sveglia, va bene.

Buon giorno, signora. Dormido bene? Io? Non dormido bene.

Ma non domanda mai come dormido io. Parlo in pranzo.

Sto male, signora, non posso servire tavolo. Non so perché.

Ma se io so, perché devo dire che non so?

Signora... io voglio bene te e il padrone, ma... ricordo mio paese e penso... tutta notte... tutto giorno.

No. Di fretta.

Voglio tornare mio paese perché là io canto sempre io male qui voglio andare via comprende signora? 
Così non comprende niente. Allora, piano, racconto vita nel mio paese. (Brito 1998: 29)

Madam, I don't feel good in Italy. I go back.

No, not like this. Better little by little.

Madam, don't mind? I want talk. I have little problem and I want solve with you.

Yes, when you wake, is good.

Good morning madam. You sleeped well? I? Not sleep well.

But she never ask how I sleep. I talk during the lunch, so. I feel sick, madam, I can't serve the table. I not know why.

But if I know, why say I not know?

Madam... I like you and the doctor but... I remember my country... and... I think all night and... day too.

No, no time.

I want go back to my town because there I sing always. I feel sick here. I want go away. Understand, madam?

This way she understands nothing. So, slow. I tell the life in my town. ${ }^{5}$

Ana is one of the many immigrant women who appear in the short stories in Brito's collection Amanda, Olinda, Azzurra e le altre, and who experience loneliness and isolation in Italy, their land of adoption. The writer often depicts her female characters as afflicted by solitude, saudade, dislocation and displacement, and the contrast between the heaviness of the events represented and the lightness of the characters and of the language they speak often makes the situations more vivid and, at times, tragic.

The language Ana speaks is 'Portulian', a combination of Portuguese and Italian ${ }^{6}$. When Brito was asked about the Portulian of

English translation by Rodolfo A. Franconi and Graziella Parati, in: Graziella Parati (ed.), Mediterranean Crossroads: 162. 
her characters, she claimed that this hybrid language is the outcome of her thinking in Portuguese and translating into bad Italian, and that, in general, it is more difficult for her to write in proper Italian than it is to write in Portulian. Retracing the genesis of this language, the writer also establishes parallels among different transnational movements and their outcomes when she claims that: "gli emigranti italiani in Brasile parlavano un po' così, mescolando l'italiano e il portoghese ma in realtà parlavano in 'portuliano,' come alcuni dei miei personaggi" ("Italian emigrants in Brazil used to speak a little like this, mixing Italian and Portuguese, but in reality they spoke 'Portulian', like some of my characters")'

In stories like 'Ana de Jesus' and 'Olinda' (the story of a Brazilian former prostitute who is hired as a maid by a small town parish priest and who decides to leave her job and the town when the bad reputation of her previous life starts affecting the priest), Brito dignifies the experiences of these migrant women by codifying the oral language of Brazilian immigrants into writing. Portulian is their way of translating their experience into language - a task that neither Portuguese nor Italian could accomplish independently from each other - a language that speaks about dislocation and deterritorialization, poverty and exploitation. The political and social impact of such a use of language has been theorized by feminist intellectuals like Gloria Anzaldúa, who claims that legitimizing one's language means legitimizing one's identity. According to Anzaldúa, Chicano Spanish, Spanglish, Tex-Mex must not be considered as improper languages, not quite English, but not quite Spanish either, languages ridden with mistakes no matter what perspective one assumes, languages to be ashamed of. These are frontera languages, the languages of people whose identities have changed due to

6 For an analysis of Brito's use of Portulian, see Sonia Sabelli, "Transnational Identities”.

Carla Collina's interview to Christiana de Caldas Brito, to which I refer here, is quoted in Sonia Sabelli, "Scrittrici eccentriche: Identità transnazionali nella letteratura italiana", doctoral dissertation, University of Rome "La Sapienza", 2004:70. 
transnational movements and to new borders imposed by wars. The creation of border languages enables these people to fill the gap existing between the signifiers of these languages and the signified inscribed in their experience, and to avoid what Ngugi wa Thiong'o in a different context calls "colonial alienation" (Ngugi 1986:17). New experiences need to be embodied in new languages:

Chicano Spanish is considered by the purist and by most Latinos deficient, a mutilation of Spanish. But Chicano Spanish is a border tongue which developed naturally. Change, evolución, enriquecimiento de palabras nuevas por invención o adopción have created variants of Chicano Spanish, un nuevo lenguaje. Un lenguaje que corresponde a un modo de vivir, Chicano Spanish is not incorrect, it is a living language. (Anzaldúa 1987:77)

In this language, in which the very notion of purity is rejected because this is the voice of people whose lives are not marked by purity, homogeneity, and sameness, rather by dislocation, marginalization, mestizaje, Anzaldúa moves from English to Spanish without solution of continuity, italicizing the parts in Spanish but not providing a translation for them. Visually, as well as conceptually, this process authorizes her language: if her life and the lives of many are inbetween, so is the language they speak $^{8}$. The same strategy is employed by Ubax Cristina Ali Farah in her novel Madre piccola, where words in Somali are interspersed in her narration in Italian. The novel opens with the words "Soomaali baan ahay, come la mia metà che è intera" (Ali Farah 2007:1). For this expression in Somali no translation is provided within the text or in footnotes (although there is a glossary at the end of the book). Borderless languages such as

8 Although I do not discuss it here, central in the work of Gloria Anzaldúa, as well as of other Chicana writers such as Cherrie Moraga and Ana Castillo, is the recovery of the Amerindian cultural heritage of Chicana women. In their texts, Indian words often appear next to English and Spanish. 
Anzaldúa's and Ali Farah's produce an effect of displacement and lack of understanding in mainstream readers - non-Chicano readers in the United States and non-Somali readers in Italy - who are forced out of their position of centrality within their language and culture, and whose language is at the same time appropriated and rejected.

A somewhat similar use of language is made by Italian American and African American filmmaker and writer Kym Ragusa ${ }^{9}$. In her memoir The Skin Between Us, she often uses words that are part of the mixture of Italian dialects and standard Italian that her Italian American family used to speak. Interestingly, these terms are most used when she refers to religion and food, two central aspects of her family's life and experience, aspects that connect her to the Italian peasant tradition of her family: "I would pick fragments of their conversations, What a shame and Santamariagesu" (Ragusa 2006:182) or "[...] calling out all the things he planned to grow: Pomodori! Zucchini! Melanzane!" (2006:187). As interesting as the use of the Italian language of her Italian American side of the family or, to be more precise, of the variant of Italian that second-, third-, and fourth-generation Italian Americans used and still use - is Ragusa's determination to keep the "impurity" of their language in her written text. The fact that some of the expressions are not exactly right and some of the words in Italian or dialect are occasionally misspelled reproduces the way in which her family would actually speak the language. By privileging the voice of her family over the authority of grammar and syntax (or even over the correctness of dialect), Ragusa rejects the authority and officiality of high Italian, proper dialects, and writing, legitimizing the migrants' language, and their experience, and privileging the orality of their working-class origins ${ }^{10}$.

9 For a discussion of Gloria Anzaldúa's and Kym Ragusa's resistance through language, see Caterina Romeo, "Una capacità quasi acrobatica".

10

This reflection comes out of my personal experience with the author. After reading the galleys of The Skin Between Us that Kym had given me, I emailed her to ask if she wanted me to correct the mistakes in Italian or in the Calabrese dialect that were present in the text (my family, as Kym's, is from Calabria), which I did not think the readers at Norton Press 
When analyzing languages of experience, such as Ana de Jesus's in Christiana de Caldas Brito's short story, it is crucial to consider the space in which the lives of migrants unfold. Unlike men, whose initial work experiences in Italy are often related to public spaces - as we learn in early texts such as Pap Khouma's Io venditore di elefanti, Mohamed Bouchane's Chiamatemi Ali, Salah Methnani's Immigrato, only to mention a few - migrant women are still too often confined to the enclosed space of domesticity. The resistance that Ana de Jesus enacts in her language, therefore, intersects with other kinds of resistance that question relationships among women - in Italy and elsewhere -and the very notion of global feminism. What emerges from Ana's language is not just a migrant's sense of displacement in a new world. Ana is nervous at the prospect of telling her employer of her imminent departure because she knows that she will be accused of being ungrateful and not worthy of all the kindness and the privileges that she has received from her employers. If her solitary rehearsal expresses the migrant's idealization of her world of origin, this is also a sharp feminist critique of the power relationships existing among women who come from different geopolitical locations. Not only does Ana's language resist mainstream Italian culture through the invention of another Italian language, it also resists sisterarchal relationships among women, denouncing the exploitation of female domestic workers in Italy by privileged, white, Italian women, unaware of, or indifferent to, the system of global inequality that they perpetuate and reinforce $^{11}$. By denouncing the exploitation of women from the Third

would catch. In spite of years and years of Italian American studies, I grimace every time I find a word misspelled in Italian or in one of the dialects I know, arguing for the necessity of accuracy and purity in the language of a culture which has its roots in the Italian working class, which is the result of transmigration and transculturation, and which, therefore, is not characterized by spelling accuracy. Kym responded to my need of cleanliness and precision and to my embodiment of the authority of official language with her determination to keep the mistakes in the written text. She argued that the fact that she does not know how these words are written is precisely part of her inheritance and of the process of "bastardization" of the language that her family went through when they migrated to the United States.

For a representation, more than an explanation, of the notion of "sisterarchy", see Nkiru 
World by western women, Brito joins feminist movements of black, Chicana and Latina, migrant women, and in general of non-privileged women who question the notion of "global sisterhood" that in Italy - a country where, as Wendy Pojmann argues, massive immigration of women has not resulted in a re-articulation of feminist discourses - is still very resistant ${ }^{12}$.

Ingy Mubiayi denounces the same power relationships between white Italian and immigrant women in the short story 'Documenti prego'. She does it with the lightness and the irony that often characterize the writing of second-generation women authors: the protagonist of the story ironically praises the benevolence of the woman who has agreed to sponsor her mother - one of the many "benefactresses", as women who hire immigrant maids like to think of themselves - which has resulted in their finally being able to apply for citizenship. In exchange for this generosity, "as was the habit in civilized countries", her mother had to work without remuneration ${ }^{13}$.

If the invention of the Portulian language of experience and the denunciation of sisterarchal relationships among women constitute important ways of resisting and redefining Italian mainstream culture, an equally powerful way of enacting resistance in Brito's 'Ana de Jesus' is her emphasis on orality. This element is central both in the structure of the story, which is articulated as an imagined monologue, and in the strategies employed in the narration often typical of oral narrative (repetition, questions to the reader, pauses, suspense). The character of the storyteller even appears in the narrative in the person of Ana's grandmother Dedè, who used to entertain her grandchildren with stories while sewing under the moonlight. Interestingly, Dedè is introduced when Ana is left without an audience, when she imagines

Nzegwu's poem "Sisterhood".

12 For an articulation of the interaction between immigrant women and feminism in Italy - or the lack thereof - see Wendy Pojmann, Immigrant Women and Feminism in Italy.

In the Italian text on page 105. 
her employer telling her that she has no time to listen to her. Ana responds to the employer's (imagined) attempt to establish a linguistic supremacy over her by privileging the language of orality and the immediacy of sound and rhythm over the correctness of grammar and syntax ("Se le mie parole tengono un ritmo, e se tu capisci il ritmo, perché non posso sbagliare le parole?" Brito 1998:33) ("If my words have a rhythm and if you understand the rhythm, why can't I mistake the words?"). The strategies of storytelling - repetition, pauses, silences, creation of tension and suspense, absence of explanation of the story's meaning - are reproduced in Ana's narration: the effect that the short story produces on the readers is that of listening to, rather than reading, a story. Dedè's storytelling is Ana's way to reconnect to her past, to a world in which the act of telling stories was a valuable part of cultural processes and of the acquisition of knowledge. Language, then, is yet another element that separates Ana from the white woman: the languages they speak (proper Italian, which privileges grammatical and syntactical correctness vs. Portulian, which privileges rhythm and sound) express the different positions of power they occupy in the world.

Orality is a strong characteristic also in Eritrean Italian writer Ribka Sibhatu's first book, Aulo, in Italian with parallel text in Tigrinya. The aulo is an oral poem-chant which constitutes a popular genre in Eritrea, and which is "handed down through narration" placing so much emphasis on orality, Sibhatu confers authority to her culture of origin and dignifies the experience of her people, while at the same time undermining the normative power and the authority of writing. The book, published in Italy as part of a series designed to introduce school children to the notion of multiculturalism, tells the habits and traditions of her country, while at the same time recounting her escape from Asmara, her "voluntary exile" in Addis Ababa, and the author's arrival in Italy. In what can be read as a celebration of Sibhatu's land of origin, to which she returned for the first time in

14 In the Italian text on page 60 
1992 after a long exile, Sibhatu also denounces the patriarchal oppression in her native culture and the racialization of Eritrean people enacted by Italian colonizers.

The centrality of orality in Regina di fiori e di perle, the first novel written by Ethiopian Italian writer and performer Gabriella Ghermandi, is affirmed in the opening of the text, when the old men who inhabit the young protagonist's household predict that she will become their people's storyteller: "Un giorno sarai la nostra voce che racconta. Attraverserai il mare che hanno attraversato Pietro e Paolo e porterai le nostre storie nella terra degli italiani" ("One day you will be our narrating voice. You will cross the sea that Peter and Paul have crossed and you will bring our stories to the land of Italians") (2007:6). Those Italians who, until very recently, have tried to erase their colonial history are now forced to listen to it in the voice of the colonized. Like Caliban, who used Prospero's language to curse, the protagonist of Ghermandi's novel learns the Italian language and the colonial history of her country to be able one day to recount that story to the colonizers, thus forcing them to reconsider one of the most obscure and painful pages of their national history.

The language employed by second generations - what I define as post-migrant writers - is different both from the language of the first generations and from that of "mainstream" Italians ${ }^{15}$. The attitude of second-generation writers both towards the countries of their parents and towards the Italian language and culture differs substantially from migrant writers. Although post-migrant writers often retain a strong sense of their origins, generally they have acquired enough distance to be able to think of their lands of origin not only - and sometimes not at all - with a sense of longing, but also in very critical terms. At the same time, they often treat the purity and the nobility of the Italian language and culture with irony, irreverence, and open disrespect.

15 I do not mean to suggest that the language of second generations is in some way homogeneous. What I do mean to suggest, as mentioned before and specified here, is that their attitude towards Italian language is generally characterized by the confidence of native speakers, to which a nuance of irony and irreverence is often added. 
Italian no longer intimidates them: it is often their first language or the language of their education and, although they are at times still perceived as different, especially if they are of a different color, they no longer need to prove that they can use the Italian language correctly. As a result, their writings are often experimental, both in their use of language (invented languages, colloquial expressions, curse words, oral language) and in the themes they develop in their stories, which often question both their parents' cultures of origin and of arrival.

In Igiaba Scego's short story 'Dismatria', which opens the collection questionably entitled Pecore nere (which means "black sheep"), the protagonist fears her mother's reaction once she will disclose to her the news that she has bought an apartment and that she plans to move into it. She knows that her mother will interpret her wanting to grow permanent roots into the Italian soil as a betrayal of their native Somalia. Although her family has lived in Italy for many years, their fear of permanence in their host country has translated into a stubborn resolution not to grow any roots: they have resolutely refused to buy a closet and have been keeping all their belongings in suitcases for years. This arrangement allows them to maintain the illusion of being ready to return to their country of origin if and when the possibility presents itself:

Eravamo in continua attesa di un ritorno alla madrepatria che probabilmente non ci sarebbe stato. Il nostro incubo si chiamava dismatria. Qualcuno a volte ci correggeva e ci diceva: "In italiano si dice espatriare, espatrio, voi quindi siete espatriati." Scuotevamo la testa, un sogghigno amaro, e ribadivamo il dismatria appena pronunciato. Eravamo dei dismatriati, qualcuno - forse per sempre - aveva tagliato il cordone ombelicale che ci legava alla nostra matria, alla Somalia. E chi è orfano di solito che fa? Sogna. E così facevamo noi.... In cuor nostro sapevamo che non saremmo più tornati nella nostra Somalia, perché di fatto non esisteva più la nostra 
Somalia. Ma piuttosto che ammettere questa semplice verità, preferivamo prenderci in giro da soli. La Somalia, quella sognata, quella vagheggiata, quella desiderata, sopravviveva solo nei nostri sogni ad occhi aperti, nelle chiacchiere notturne delle donne, nell'odore del cibo delle feste, nei profumi esotici dei nostri capelli. (Scego 2005:11)

We were perpetually waiting to go back to our motherland, which would probably never happen. Our nightmare was called dismatria. Someone at times corrected us and told us: "In Italian you say 'expatriate', therefore you are 'expatriate'." We shook our heads, a bitter sneer, and reasserted the dismatria that we had just uttered. We were dismatriate, someone had cut the umbilical cord which tied us to our matria, Somalia, maybe forever. And what do orphans do? They dream. And this is what we did.... In our hearts we knew that we would never go back to our Somalia, because our Somalia no longer existed. But rather than admitting this simple truth, we preferred to fool ourselves. Somalia, dreamed, longed for, desired, survived only in our daydreams, in the nocturnal chats of women, in the smell of food at parties, in the exotic perfumes in our hair.

Just like Rushdie's "imaginary homelands", real places where layers of memories, longing, and desire have accumulated over the years, transforming them into places of the mind, the Somalia that the family in Scego's story has abandoned no longer exists. Not only has it become distant in time as well as in space, but it has also been devastated by the violence of war. The hiatus between the different generations becomes apparent throughout the story, in which the protagonist wants to renounce her family's sense of impermanence and their life as "dismatriate". Native Italians, however, attribute the use of the neologism "dismatriate" instead of the Italian word "espatriate" 'expatriate' to these Somali women's presumed poor 
knowledge of Italian. Not only is their land of origin seen as a "mater", a mother (as in dismatria) rather than as a "pater", a father (as in espatriare, to expatriate). The Latin prefix "dis" implies a sense of separation, or dispersion, which is not present in the prefix "ex", which only conveys the idea of being or going out. This term, therefore, does not indicate the condition of being outside of one's fatherland; rather, it defines the separation from one's mother, a separation, like the one at birth, which is irreconcilable. Rather than revealing a poor knowledge of Italian, words like "dismatria" express these women's necessity to create new words that are able to carry the significance of their experience.

The nervousness and tension of the protagonist, whose desire to achieve a sense of permanence will make her a traitor in her mother's eyes, is expressed both in her use of language and in the structure of the story. Scego conveys a sense of tension in the narrative by disorienting the reader. The writer produces this effect by rejecting linearity and by de-centering the narrative through the insertion of incidents and digressions that continuously bring the narrative elsewhere. Disorientation is also achieved through linguistic choices. The language that Scego employs in her narration is characterized by different registers ranging from formal, high-style Italian, to colloquial language, to a frequent and abrupt use of curse words, that generally are in strong contrast with the preceding tone and atmosphere and that create a moment of shock.

This sense of diversion and distraction, frequently introduced in the narration to momentarily relieve the tension that has become too high, is also achieved through comic relief. In the scene in which, after many diversions and incidents, the narration escalates towards the disclosure of the news, the point of view through which the reader perceives the events doubles, although the voice is only that of the protagonist. On the one hand, the narrator keeps diverting the reader's attention by inserting elements such as the appearance of her Brazilian transsexual friend, Angelique, whose flamboyant presence and abundant breasts distract both the reader and the protagonist's family 
from more important issues. On the other hand, however, the narrator's mother's vigilant eye on the events - she is the only one who is not fooled by all the distractions - creates another point of view for the reader, whose attention is alternatively distracted and restored. The tension in the narration reaches its highest level when the protagonist's mother decides to stop the farce and tell Angelique that she is not welcome there, both because she is not part of the family and because she is a "deviant", a "homosexual". Although the tension in the narration is high, the disclosure of the news is once again postponed and another element of distraction introduced, which produces an effect of comic relief: Mulki, the protagonist's cousin, directly questions Angelique about her breasts, which everyone has been admiring since their appearance in the room:

"Se apro [la valigia] mi dici dove ti sei rifatta le tette?"

"In Marocco baby, a Casablanca."

"Marocco..." ripeté tra sé la ragazzina, quasi non capacitandosi che le tette stratosferiche venivano dal paese che fabbricava più immigrati nel mondo. (2005:18)

"If I open [the suitcase] are you going to tell me where you had your tits done?"

"In Morocco, baby, in Casablanca."

"Morocco..." the girl muttered to herself, almost unable to believe that the stratospheric tits came from the country that produced more immigrants in the world.

Angelique, a Brazilian transsexual who lives in Italy, embodies the multiple levels of difference and transmigration that are present in this story. Not only is her identity formed at the intersections of different sexualities, nationalities, cultures, and languages; even her new sexual identity is related to a country, Morocco, which in Italy is considered as the quintessential source of immigrants ${ }^{16}$.

16 The term "marocchino", Moroccan, has been and sometimes still is used in Italy as a 
Although the short story starts with the encounter/dichotomy of the two countries at the intersection of which the writer's and the protagonist's identities are formed, it soon goes far beyond the binary opposition Italy/Somalia to embrace a number of transmigrations, differences, othernesses, which often characterize the societies that post-migrant writers such as Scego represent. Even the relationship between Italy and Somalia at the end of the story is not one of dichotomy but of simultaneous presence and significance. When in the final scene all the suitcases are opened, one of them is found to contain "a pack of spaghetti, photos of monuments in Rome, the hairs of a cat, a plastic piece of parmesan, a kitschy souvenir of the shewolf breastfeeding the twins, a little soil in a small bag, a little bottle full of water, a stone" ${ }^{\prime 17}$. This collection of cultural, even stereotypical, icons signals this Somali woman's desire to bring her adoptive country with her, if she is ever able to go back to her motherland ${ }^{18}$. The border between adoptive country and motherland, then, becomes blurred and is trespassed. The protagonist's mother is aware - and makes the reader aware - of the fact that the act of leaving renders returning always partial. Even if the protagonist's mother has idealized Somalia and has been ready for years to leave her adoptive city, Rome, she is aware that migration is an irreversible process and that, after migration, a univocal national identity is no longer possible.

The kind of resistance that migrant and post-migrant writers enact in their literature is interpreted by Graziella Parati as their way of "talking back" to the legal system, which denies them individual identities and legal rights. In the text that the legal system writes in

synonym for "immigrant".

17 In the Italian text on page 21.

18 Together with easily recognizable Italian cultural icons, like spaghetti and parmesan, and natural elements, such as the soil and the water, the other objects that the protagonist's mother has collected to bring with her are symbols of Rome: stray cats dwell in the Coliseum, the twins breastfed by the she-wolf are Romulus and Remus, and the stone is a metonymic presence of the Roman ruins. 
Italy, migrants are represented as undesired and undesirable guests, whose access needs to be controlled, limited, even impeded: in this national narrative, migrants are inscribed as a voiceless, amorphous, and undifferentiated collectivity. The literature and films of migrant authors are their personal and individual response, the texts through which they inscribe their individual and collective presence in the Italian national narrative, which they contribute to rewrite. Women writers, moreover, question their relationship with Italian women, while at the same time recovering narratives that have been erased from Italian history, connecting Italy's past to her present as a nation of immigrants. Through their rich corpus of works, both in the themes treated and in their use of language, migrant and post-migrant women writers in Italy are actively working to transform the very notion of "italianness". If authorship is a strategy to acquire authority, these artists are claiming - and obtaining - the right to become (legal) subjects of representation in the Italian culture.

(Università La Sapienza, Roma) 